Bangladesh Journal of Neuroscience 2008; Vol. 24 (1) : 24-33

\title{
Dyslipidaemia in Cortical Versus Subcortical Infarction
}

TARUN KANTI SARKER ${ }^{1}$, MD RUHUL KUDDUS $^{1}$, MD REZAUL KARIM KHAN ${ }^{2}$, AKM ANWAR ULLAH ${ }^{3}$, MD RAFIQUL ISLAM ${ }^{2}$, ANISUL HAQUE ${ }^{4}$

\begin{abstract}
Objectives: The aim of the study was to predict risk of cerebral infarction either cortical or lacunar in population having dyslipidaemia and to create awareness regarding it as a risk factor for ischaemic stroke and to take preventive measures for the prevention of a first or recurrent ischaemic stroke.
\end{abstract}

Method: This study was conducted in the Department of Nurology, Bangabandhu Sheikh Mujib Medical University (BSMMU), Dhaka from March to October, 2006. This study included 30 acute ischaemic stroke patients diagnosed by history, clinical findings and confirmed by CT/MRI scan of head within 2 weeks of attack. Both man and woman age ranging from 40-90 years were eligible to enter into the study. The same number of age and sex matched nonstroke patients who gave blood for analysis were included as control.

Result: In this study among other risk factors total serum cholesterol was raised in both cortical and lacunar infarct in 50\% of cases in comparison to $33.3 \%$ controls $(P<0.05)$. LDL-cholesterol levels were raised in both cortical and lacunar infarct in $50 \%$ of cases compared to $30 \%$ controls $(P<0.05)$.
HDL-cholesterol levels were significantly low in cases (70\%) compared to control subjects (26.7\%). It was significantly low in cases of cortical infarct (77.3\%) compared to $50 \%$ cases of lacunar infarct $(P<0.01)$.

Serum triglyceride levels were raised in $60 \%$ of case group and $26.7 \%$ of control subjects $(P<0.01)$. Serum triglyceride levels were raised in $54.5 \%$ cases of cortical infarcts compared to $75 \%$ cases of lacunar infarcts.

Conclusion: The results indicate an association between dyslipidaemia and the risk of ischaemic stroke, specially cortical type. Dyslipidaemia more related to cortical infarct than subcortical infarct. Low level of HDL-cholesterol was related to cortical infarct but not with subcortical infarct.

\section{Introduction}

According to World Health Organization (WHO), stroke may be defined as sudden development of neurological deficit, focal or global, persisting for more than 24 hours or patient dies within 24 hours, which is vascular in origin and non-epileptic and nontraumatic in nature ${ }^{1}$. Stroke, after heart disease and cancer, is the third most common cause of death after the age of $40^{2}$.

1. MD (Neurology) Student, Bangabandhu Sheikh Mujib Medical University (BSMMU), Shahbag, Dhaka.

2. Associate Professor, Department of Neurology, BSMMU, Shahbag, Dhaka.

3. Professor, Department of Neurology, BSMMU, Shahbag, Dhaka.

4. Professor \& Chairman, Department of Neurology, BSMMU, Shahbag, Dhaka. 
Stroke is the commonest neurological disorder of adult life and about 50 percent of the neurological diseases among adult admitted patients in a general hospital, and it is also the leading cause of disability in adults $^{3}$. Of all the stroke cases, 85 percent are due to ischaemic infarction and 15 percent are due to haemorrhage ${ }^{4}$.

There is no fundamental study regarding the relationship between blood lipids and ischaemic stroke among Bangladeshi population, but there are studies which show hypercholesterolaemia is a risk factor for stroke ${ }^{5}$.

Bangladesh is a developing country and her health budget is minimum. Strokes are causing a great burden for the family, society, community as well as the nation. So, we should think about known modifiable risk factors of stroke, proper control of which plays an important role in the primary prevention of the disease.

\section{Materials and Methods}

This study was conducted in the Department of Nurology, Bangabandhu Sheikh Mujib Medical University (BSMMU), Dhaka from March to October, 2006. This study included 30 acute ischaemic stroke patients diagnosed by history, clinical findings and confirmed by CT/MRI scan of head within 2 weeks of attack. Both man and woman age ranging from 40-90 years were eligible to enter into the study. The same number of age and sex matched nonstroke patients who gave blood for analysis were included as control.

Age, sex, risk factors for stroke such as hypertension, hypercholesterolaemia, cigarette smoking, diabetes mellitus, history of previous stroke or TIA were evaluated in all patients, together with symptoms of stroke. Hypertension was diagnosed when the blood pressure measured in the hospital was $>160 / 95 \mathrm{~mm}$ $\mathrm{Hg}$ or if the patient was taking antihypertensive agents. Glucose intolerance was diagnosed if a patient was using oral hypoglycemic agents or insulin and/or if the fasting blood glucose level in the hospital exceeded $6.1 \mathrm{mmol} / \mathrm{L}$ and $/$ or the glycosylated hemoglobin level exceeded 6.4\%. Hypercholesterolemia was, diagnosed if a patient was taking lipidlowering agents and / or if the serum cholesterol level exceeded $200 \mathrm{mg} / \mathrm{dl}$. Patients were categorized as being either nonsmokers (never smoked cigarettes or quit $>3$ years ago) or smokers (current smoker) or gave up cigarette smoking $<3$ years ago.

All relevant informations were recorded in a predesigned questionnaire. Collected data were complied and appropriate analyses were carried out using computer based software, Statistical Package for Social Science (SPSS). P value $<0.05$ was taken as minimum level of significance.

\section{Results}

A total number of 30 cases and 30 controls were enrolled in the study. Table-I to XII demonstrates the comparison of some basic data between case and control groups. Majority of the subjects presented at sixth to seventh decade of life. A high frequency of hypertension, smoking, diabetes and hypercholesterolaemia were found in case group. Table-I showed that mean ( $\pm-S D$ ) age of the case and control groups were $60.93 \pm 10.70$ and $57.90:$ L12.14 years respectively. Table-II showed there were $70 \%$ males in case and $63.3 \%$ in 
control groups. There were $30 \%$ females in cases and $36.7 \%$ in control groups. The male: female ratio in case and control groups were 1:0.43 and 1:0.58, respectively. Table-III showed that smoking habit was significantly associated as risk factor for ischaemic stroke in $66.7 \%$ of case group. Table-IV showed that diabetes mellitus was present in $33.3 \%$ of cases and in $10 \%$ control subjects. Table- $\mathrm{V}$ showed that $60 \%$ cases were hypertensive compared to $20 \%$ in control group. Table-VI showed status of serum total cholesterol levels in cortical and subcortical infarct cases and in controls. Table-VII showed serum HDL-cholesterol was significantly low in cortical infarct cases (77.3\%). Table-VIII showed that LDLcholesterol was not significantly associated with either cortical or subcortical infarct cases and controls. Table-IX showed association of triglyceride and infarction. Triglyceride was raised in maximum number of both cortical and subcortical infarct groups. Table- $X$ showed total serum cholesterol level in case and control groups. Table-XI showed HDL-cholesterol was significantly low in $70 \%$ cases compared to $26.7 \%$ control. Table-XII showed normal LDL-cholesterol label in $50 \%$ and raised in rest $50 \%$ cases, whereas LDL-cholesterol was raised in $30 \%$ subjects of control groups. Table-XIII showed serum triglyceride levels were raised in $60 \%$ subjects of case groups and $26.7 \%$ subjects of control groups.

Table-I

Age distribution of the study subjects ( $n-30$, for both cases \& controls)

\begin{tabular}{lccc}
\hline Age group(years) & Number (\%) & Number (\%) & P value \\
\hline $40-59$ & $4(13.3)$ & $10(33.3)$ & \\
$50-59$ & $7(23.3)$ & $7(23.3)$ & \\
$60-69$ & $11(36.7)$ & $4(13.3)$ & $>0.05^{\text {ns }}$ \\
$70-79$ & $6(20.0)$ & $9(30.0)$ & \\
$80-89$ & $2(6.7)$ & 00 & \\
Mean \pm SD & $60.93 \pm 10.70$ & $57.90 \pm 12.14$ & $>0.10^{\text {ns }}$ \\
\hline
\end{tabular}

Chi-square test/Unpaired Student's 't' test. $\mathrm{ns}=$ not significant

Table-II

Sex distribution of the study subjects ( $n-30$, for both cases \& controls)

\begin{tabular}{lccc}
\hline Sex & Number (\%) & Number (\%) & P value \\
\hline Male & $21(70.0)$ & $19(63.3)$ & \\
Female & $9(30.0)$ & $11(36.7)$ & $>0.50^{\text {ns }}$ \\
\hline
\end{tabular}

Chi-square test, ns= not significant 
Table-III

Status of smoking habit of the study subjects

\begin{tabular}{lccc}
\hline Smoking habit & $\begin{array}{c}\text { Case }(\mathrm{n}=30) \\
\text { Number }(\%)\end{array}$ & $\begin{array}{c}\text { Control }(\mathrm{n}=30) \\
\text { Number }(\%)\end{array}$ & P value \\
\hline Present & $20(66.7)$ & $8(26.7)$ & $<0.01$ ** \\
Absent & $10(33.3)$ & $22(73.3)$ & \\
\hline
\end{tabular}

Chi-square test ${ }^{*}=$ significant.

Table-IV

Status of diabetes mellitus of the study subjects

\begin{tabular}{lccc}
\hline Diabetes mellitus & $\begin{array}{c}\text { Case }(\mathrm{n}=30) \\
\text { Number (\%) }\end{array}$ & $\begin{array}{c}\text { Control }(\mathrm{n}=30) \\
\text { Number }(\%)\end{array}$ & P value \\
\hline Present & $10(33.3)$ & $3(10.0)$ & $<0.05^{*}$ \\
Absent & $20(66.7)$ & $27(90.0)$ & \\
\hline
\end{tabular}

Chi-square test

* = significant.

Table-V

Status of hypertension of the study subjects

\begin{tabular}{lccc}
\hline Hypertension & $\begin{array}{c}\text { Case }(\mathrm{n}=30) \\
\text { Number }(\%)\end{array}$ & $\begin{array}{c}\text { Control }(\mathrm{n}=30) \\
\text { Number }(\%)\end{array}$ & P value \\
\hline Present & $18(60.0)$ & $6(20.0)$ & $<0.01$ * \\
Absent & $12(40.0)$ & $24(80.0)$ & \\
\hline
\end{tabular}

Chi-square test

* = significant.

Table-VI

Association of serum total cholesterol and infarction

\begin{tabular}{lcccc}
\hline $\begin{array}{l}\text { Serum total } \\
\text { cholesterol } \\
(\mathrm{mg} / \mathrm{dl})\end{array}$ & $\begin{array}{c}\text { Cortical } \\
\text { infarct }(\mathrm{n}=22) \\
\text { No. }(\%)\end{array}$ & $\begin{array}{c}\text { Subcortical } \\
\text { infarct }(\mathrm{n}=8) \\
\text { No. }(\%)\end{array}$ & $\begin{array}{c}\text { Control }(\mathrm{n}=30) \\
\text { No. }(\%)\end{array}$ & P value \\
\hline$<200$ (normal) & $11(50.0)$ & $4(50.0)$ & $20(66.7)$ & $>0.10^{\text {ns }}$ \\
$>200$ (raised) & $11(50.0)$ & $4(50.0)$ & $10(33.3)$ & \\
\hline
\end{tabular}

Chi-square test

ns $=$ not significant. 
Table-VII

Association of HDL-cholesterol and infarction

\begin{tabular}{|c|c|c|c|c|}
\hline \multirow{3}{*}{$\begin{array}{l}\text { HDL-cholesterol } \\
(\mathrm{mg} / \mathrm{dl})\end{array}$} & \multicolumn{2}{|c|}{ Case $(n-30)$} & \multirow{4}{*}{$\begin{array}{c}\text { Control }(n=30) \\
\text { No. }(\%)\end{array}$} & \multirow{4}{*}{$\begin{array}{c}\mathrm{P} \\
\text { Value }\end{array}$} \\
\hline & Cortical & Sub-cortical & & \\
\hline & Infarct $(n=22)$ & infarct $(n=8)$ & & \\
\hline & No. (\%) & No. (\%) & & \\
\hline \multirow[t]{2}{*}{$<40$ (low) } & $17(77.3)$ & $4(50.0)$ & $8(26.7)$ & \\
\hline & & & & $<0.01$ ** \\
\hline$>40$ (normal) & $5(22.7)$ & $4(50.0)$ & $22(73.3)$ & \\
\hline Total & $22(100 \%)$ & $8(100 \%)$ & 30 (100\%) & \\
\hline
\end{tabular}

Chi-square test

** = significant

Table-VIII

Association of LDL-cholesterol and infarction

\begin{tabular}{llcccc}
\hline \multirow{2}{*}{$\begin{array}{l}\text { LDL-cholesterol } \\
(\mathrm{mg} / \mathrm{dl})\end{array}$} & $\begin{array}{c}\text { Cortical } \\
\text { Infarct }(\mathrm{n}=22) \\
\text { No. }(\%)\end{array}$ & $\begin{array}{c}\text { Sub-cortical } \\
\text { infarct }(\mathrm{n}=8)\end{array}$ & $\begin{array}{c}\text { Control }(\mathrm{n}=30) \\
\text { No. }(\%)\end{array}$ & $\begin{array}{c}\mathrm{P} \\
\text { Value }\end{array}$ \\
\hline$<130$ (normal) & $11(50.0)$ & $4(50.0)$ & $21(70.0)$ & \\
& & & & $>0.10^{\mathrm{ns}}$ \\
$>130$ (raised) & $11(50.0)$ & $4(50.0)$ & $9(30.0)$ & \\
\hline
\end{tabular}

Chi-square test ns= not significant.

Table-IX

Association of triglyceride and infarction

\begin{tabular}{|c|c|c|c|c|}
\hline \multirow{4}{*}{$\begin{array}{l}\text { Triglyceride } \\
(\mathrm{mg} / \mathrm{dl})\end{array}$} & \multicolumn{2}{|c|}{ Case (n-30) } & \multirow{4}{*}{$\begin{array}{c}\text { Control }(n=30) \\
\text { No. }(\%)\end{array}$} & \multirow{4}{*}{$\begin{array}{c}\mathrm{P} \\
\text { Value }\end{array}$} \\
\hline & Cortical & Sub-cortical & & \\
\hline & Infarct $(n=22)$ & infarct $(n=8)$ & & \\
\hline & No. (\%) & No. (\%) & & \\
\hline \multirow[t]{2}{*}{$<150$ (normal) } & $10(45.5)$ & $2(25.0)$ & $22(73.3)$ & \\
\hline & & & & $>0.10^{\text {ns }}$ \\
\hline > 150 (raised) & $12(54.5)$ & $6(75.0)$ & $8(26.7)$ & \\
\hline Total & $22(100 \%)$ & $8(100 \%)$ & $30(100 \%)$ & \\
\hline
\end{tabular}

Chi-square test

ns= not significant. 
Table-X

Serum total cholesterol level of the study subjects

\begin{tabular}{lccc}
\hline $\begin{array}{l}\text { Total cholesterol } \\
(\mathrm{mg} / \mathrm{dl})\end{array}$ & $\begin{array}{c}\text { Case }(\mathrm{n}=30) \\
\text { No. }(\%)\end{array}$ & $\begin{array}{c}\text { Control }(\mathrm{n}=30) \\
\text { No. }(\%)\end{array}$ & P value \\
\hline$<200$ (normal) & $15(50.0)$ & $20(66.7)$ & $>0.10^{\text {ns }}$ \\
$>200$ (raised) & $15(50.0)$ & $10(33.3)$ & \\
Mean \pm SD & $206.16 \pm 41.21$ & $184.77 \pm 30.59$ & $<0.05^{*}$ \\
\hline
\end{tabular}

Chi-square test/Unpaired Student's 't' test. ns $=$ not significant

*= significant

Table-XI

$H D L$-cholesterol level of the study subjects

\begin{tabular}{lccc}
\hline $\begin{array}{l}\text { HDL-cholesterol } \\
(\mathrm{mg} / \mathrm{dl})\end{array}$ & $\begin{array}{c}\text { Case }(\mathrm{n}=30) \\
\text { No. }(\%)\end{array}$ & $\begin{array}{c}\text { Control }(\mathrm{n}=30) \\
\text { No. }(\%)\end{array}$ & P value \\
\hline$<40$ (low) & $21(70.0)$ & $8(26.7)$ & \\
& $9(30.0)$ & $22(73.3)$ & $<0.01^{\text {ns }}$ \\
$>40$ (normal) & $37.56 \pm 5.97$ & $40.97 \pm 6.66$ & $<0.05^{\star *}$ \\
\hline
\end{tabular}

Chi-square test/Unpaired Student's 't' test.

$* / * \star=$ significant

Table-XII

LDL-cholesterol level of the study subjects

\begin{tabular}{lccc}
\hline $\begin{array}{l}\text { LDL-cholesterol } \\
(\mathrm{mg} / \mathrm{dl})\end{array}$ & $\begin{array}{c}\text { Case }(\mathrm{n}=30) \\
\text { No. }(\%)\end{array}$ & $\begin{array}{c}\text { Control }(\mathrm{n}=30) \\
\text { No. }(\%)\end{array}$ & P value \\
\hline$<130$ (normal) & $15(50.0)$ & $21(70.0)$ & $>0.10^{\text {ns }}$ \\
& $15(50.0)$ & $9(30.0)$ & \\
$>130$ (raised) & $138.58 \pm 42.84$ & $118.03 \pm 35.73$ & $<0.05^{\star}$ \\
\hline
\end{tabular}

Chi-square test/Unpaired Student's 't' test.

ns= not significant

*= significant

Table-XIII

Serum triglyceride levels of the study subjects

\begin{tabular}{lccc}
\hline $\begin{array}{l}\text { Serum triglyceride } \\
(\mathrm{mg} / \mathrm{dl})\end{array}$ & $\begin{array}{c}\text { Case }(\mathrm{n}=30) \\
\text { No. }(\%)\end{array}$ & $\begin{array}{c}\text { Control }(\mathrm{n}=30) \\
\text { No. }(\%)\end{array}$ & P value \\
\hline$<150$ (normal) & $12(40.0)$ & $22(73.3)$ & $<0.10^{\star *}$ \\
& $18(60.0)$ & $8(26.7)$ & \\
$>150$ (raised) & $181.60 \pm 84.55$ & $138.00 \pm 62.01$ & $<0.05^{\star}$ \\
\hline
\end{tabular}

Chi-square test/Unpaired Student's 't' test

$* / * \star=$ significant. 


\section{Discussion}

This was an observational study and carried out to see the association of dyslipidaemia in cortical versus subcortical infarct among ischaemic stroke patients.

In this study the age range was 40 to 90 years with mean $( \pm S D) 60.93 \pm 10.70$ years in cases and $57.90 \pm 12.14$ years in controls. The male--female ratio was 1:0.43 in cases and 1:0.58 in controls.

Majority of the cases were in between 6069 years and mean age $( \pm S D) 60.93+10.70$ years. This is consistant with the study conducted by Victor and Ropper ${ }^{6}$.

In this study male female ratio was 1:0.43. Cull and Will ${ }^{7}$ showed that stroke affects males 1.5 times more often than females. In this study, $66.7 \%$ stroke patients were smoker. In a study done by Hayee et $\mathrm{al}^{8}$. showed $69.84 \%$ smokers among their stroke patients.

In this study $60 \%$ stroke patients were hypertensive. Alam et al. ${ }^{9}$ in their study of 1020 stroke patients had shown 75\% patients were hypertensive. Kannel and Wolfe ${ }^{10}$ showed that $10.24 \%$ strokes were attributable to diabetes. In this study, 33.3\% stroke patients were suffering from diabetes mellitus. This is consistent with study conducted by Karapanayiotides et al ${ }^{11}$.

In this study $50 \%$ patients had hypercholesterolaemia (both total cholesterol and LDL-cholesterol). Amarenco et al ${ }^{12}$. in their study of 250 stroke patients had shown that $31.2 \%$ cases had hypercholesterolaemia. The difference may be due to small sample size in this study.

In this observational study total cholesterol levels were (mean $\pm S D$ ) 206.16 \pm 41.21 and $184.77 \pm 30.59 \mathrm{mg} / \mathrm{dl}$ in cases and controls, respectively $(P<0.05)$. Total serum cholesterol was raised in both cortical and subcortical infracts in $50 \%$ of cases in comparison to $33.3 \%$ of controls.

LDL-cholesterol levels were (mean $\pm S D$ ) $138.58 \pm 42.84$ and $118.03 \pm 35.73 \mathrm{mg} / \mathrm{dl}$ in case and control groups, respectively $(P<0.05)$. LDL-cholesterol was raised in both cortical and subcortical infarct in 50\% of cases compared to $30 \%$ of controls.

Serum triglyceride levels (mean $\pm \mathrm{SD}$ ) were $181.60 \pm 84.55$ and $138.00 \pm 62.01 \mathrm{mg} / \mathrm{dl}$ in case and control groups, respectively $(P<0.05)$. Serum triglyceride was raised in $60 \%$ of case group and $26.7 \%$ of control subjects $(P<0.01)$.

In this study HDL-cholesterol were (mean \pm SD) $37.56 \pm 5.97 \mathrm{mg} / \mathrm{dl}$ in case group and $40.97 \pm 6.66 \mathrm{mg} / \mathrm{dl}$ in control group $(P<0.05)$. HDL-cholesterol was significantly low in cases $(70 \%)$ compared to control subjects (26.7\%) $(\mathrm{P}<0.01)$. HDL-cholesterol was significantly low in cases of cortical infarct in $77.3 \%$ cases compared to $50 \%$ cases of subcortical infarct $(P<0.01)$.

Tell et $\mathrm{al}^{13}$ showed a relationship between blood lipids and/or lipoprotein and the extent or severity of cerebrovascular atherosclerosis in all but three of 26 reviewed studies, in some of which HDLcholesterol levels were negatively associated with carotid atherosclerosis in multivariate analysis.

Salonen et al. ${ }^{14}$ found positive association with serum cholesterol and triglyceride level in their study of ischaemic stroke. Iso et al. ${ }^{15}$ in their study detected higher cholesterol level in ischaemic stroke and lower value in haemorrhagic stroke. Quizibash et al. ${ }^{16}$ in their study of TIA and 
minor stroke detected significantly higher total cholesterol, LDL-cholesterol and lower value for HDL-cholesterol in their age and sex-matched controls and concluded that high total serum cholesterol and LDLcholesterol, triglyceride and low HDLcholesterol are risk factors for ischaemic stroke. Boutron et al. ${ }^{17}$ in a study of cerebral infarct (61 cases) and 31 TIA cases compared with matched control and observed maximum increase of total serum cholesterol, LDL-cholesterol and triglyceride with decrease in HDLcholesterol.

In the Framingham study, the authors first assessed the association between HDLcholesterol and stroke prospectively, an inverse relation was identified between HDLcholesterol and atherothrombotic brain infarction among men but this was weak and non-significant. In the Copenhagen City heart study, Lindenstrom et al. ${ }^{18}$ found an inverse association between HDLcholesterol and risk of ischaemic stroke. Both studies based the analysis on a 6year follow-up. In the Framingham study, there were 51 atherothrombotic brain infarcts among a cohort of 2723 subjects and the Copenhagen City Heart Study included 279 non-haemorrhagic stroke cases among 11,342 subjects. This study showed that low serum HDL-cholesterol is a factor for ischaemic stroke.

Adam et al. ${ }^{19}$ in a study established that patients with cortical subtype of cerebral infarction were shown to have lower HDLcholesterol levels than counterparts with subcortical strokes, suggesting that HDL-cholesterol may be a risk factor for cortical but not for subcortical infarction. This study also correlates with this study as it was found that serum HDL-cholesterol was significantly low $(P<0.01)$ in cases of cortical infarct (77.3\%) but not in case of subcortical infarct.

A long-term observational study indicates that low levels of HDL-cholesterol, in addition to making an increased risk of coronary heart disease mortality, also predict ischaemic stroke mortality albeit to a lesser extent. Levels of HDL-cholesterol are determined by environmental and genetic factors ${ }^{20}$. A direct antiatherogenic role of HDL-cholesterol has been assumed because of its various potentially antiatherogenic properties, including the ability to trigger the flux of cholesterol from peripheral cells to the liver (reverse cholesterol transport) ${ }^{21}$. Physical activity ${ }^{22}$, alcohol intake ${ }^{23}$, smoking cessation $^{24}$ and possibly losing weight ${ }^{25}$ can elevate HDL-cholesterol and it has been known for a quarter of a century that drugs, such as fibric acid derivatives or niacin have the same effect.

Whether increasing HDL-cholesterol would reduce the incidence of cardiovascular disease is not yet clear. Large-scale controlled clinical trials are currently testing the efficacy of pharmacologically raising HDL -cholesterol levels among coronary heart disease patients ${ }^{26}$.

\section{Conclusion}

This case-control study showed significant differences of serum lipids in cases and controls in our community. They are important risk factors for ischaemic stroke. Dyslipidaemia is more associated with cortical infarct than lacunar infarct. It is a modifiable risk factor. So, by changing lifestyle, diet and taking regular physical exercise and losing weight in case of 
over-weight, we can reduce the risk of dyslipidaemia. We may also reduce it by taking various lipid-lowering medications if cannot be reduced by non-pharmacological measures.

\section{Recommendations}

Overall, patients need health education programme about modifiable risk factors, morbidity and mortality of stroke. Hyperlipidaemia is a modifiable risk factor, and one should be informed about its deleterious effects. This study was carried out among hospitalized patients, and sample size was small. Therefore, further community-based prospective cohort study with large sample size is required to establish dyslipidaemia as a risk factor for cortical infarct but not for subcortical infarct.

\section{References:}

1. Aho K, Harmsen P, Hatano S. Cerebrovascular disease in the community: results of a WHO collaborative study. Bull WHO 1980; 58:113-30.

2. Ropper $\mathrm{AH}$, Brown RH. Cerebrovascular disease. In: Adams and Victor's principles of neurology. 8th ed. New York: McGraw-Hill Company, Int., 2005: pp 660-746.

3. Biller J, Love BB. Ischemic cerebrovascular disease. In: Daroff $B$, Jankovic F, editors. Neurology in clinical practice. $4^{\text {th }}$ ed. $2004 ;$ pp. 1197-249.

4. Brown MM. Cerebrovascular disease: epidemiology, history, examination and differential diagnosis. Med Intern, 1996; 10: 35-41.

5. Ullah AKMA, Habib M, Mohammad QD, Ahmed S, Nahar S. Review of risk factors for stroke: study of 100 cases. Bangladesh J Neurosci 1996; 09: 1120.

6. Victor M, Ropper AH. Cerebrovascular disease. In: Adams and Victor's principles of neurology. 7th ed. New York: McGraw-Hill Companies, Inc., 2001: pp. 821-924.

7. Cull RE, Will RG. Diseases of the nervous system. In: Davidson's principles and practice of medicine. 16th ed. Hong Kong: ELBS with Churchill Livingstone, 1995: pp. 1071-9.

8. Hayee MA, Ullah AKMA, Rahman $\mathrm{MH}$, Khandaker MAK. Aetiology of young ischaemic stroke in Bangladesh. Bangladesh J Neuro 2002; 18:16-27.

9. Alam B, Habib M, Quraishi FA, Haque B, Hoque A, Mohammad QD. Stroke: evaluation of risk factors. Bangladesh J Neurosci 1999; 15:14-8.

10. Kannel WB, Wolf P. Epidemiology of cerebrovascular disease. In: Vascular disease of the central nervous system. 2nd ed. Edinburgh: Churchill Livingstone, 1983; pp. 1 -24.

11. Karapanyiotides T, PiechowskiJozwiak B, van Melle G, Bogouslavsky J. Bogouslavsky J, Devuyst G et al. Stroke patterns, etiology and prognosis in patients with diabetes mellitus. Neurology 2004; 62: 1158-62.

12. Amarenco P, Cohen A, Tzorio C. Atherosclerotic disease of the aortic arch and the risk of ischaemic stroke. N Engl J Med 1994; 331: 1474-9.

13. Tell GS, Crouse PJR, Furberg CD. Relation between blood lipids, 
lipoproteins and cerebrovascular atherosclerosis: a review. Stroke 1988; 19: 423-30.

14. Salonen JT, Puska P. Relation on serum cholesterol and triglycerides to the risk of acute myocardial infarction, cerebral stroke and death in Eastern Finnish male population. Int J Epidemiol, 1983; 12: 26-31.

15. Iso $H$, Jacobs DR Jr, Wentworth $D$, Neaton JD, Cohen JDA. Serum cholesterol levels and six years mortality from stroke in 350,977 men screened for the multiple risk factor intervention trial. N Engl J Med1989; 320: 904-10.

16. Quizibash N, Jones L, Warlow C, Mann J. Fibrinogen and lipid concentrations as risk factors for transient ischaemic attacks and minor ischaemic stroke. $\mathrm{Br}$ Med $\mathrm{J}$ 1991; 303:605-9.

17. Boutron MC, Giround M, Gras P, Gambert P, Lallemant C, Milan C, et al. Plasma lipoproteins in cortical infarction versus transient ischaemic attacks: a case control study. J Neurology 1993; 240: 133-8.

18. Lindenstrom E, Boysen G, Nyboe J. Influence of total cholesterol, high density lipoprotein cholesterol and triglycerides on risk of cerebrovascular disease: the Copenhagen City Heart Study. Br Med J 1994; 309: 11-5.

19. Adams RJ, Carroll RM, Nichols FT, MacNair N, Feldman DS, Feldman $E B$, et al. Plasma lipoproteins in cortical versus lacunar infarction. Stroke 1989; 20: 346-54.

20. Rader DJ, Brewer HB Jr. Lipids, apolipoproteins and lipoproteins. In:
Goldbourt U, de Faire U, Berg K, editors. Genetic factors in coronary heart disease. Lancet 1994; 337: 1521-6.

21. Schmitz G, Lackner KJ. High density lipoproteins and atherosclerosis. Curr Opin Lipidol, 1993; 4: 392-401.

22. Sagiv M, Goldbourt U. The influence of physical exercise on blood levels of HDL-cholesterol: implications for the risk of coronary heart disease. Int J Sports Med 1994; 15: 231-6.

23. Taskinen MR, Nikkila EA, Valimaki M, Sane T, Kuusi T, Kesaniemi Y. Alcohol-induced changes in serum lipoproteins and in their metabolism. Am Heart J 1987; 131: 458-64.

24. Goldbourt U, Medalie JH. Characteristics of smokers, non-smokers and ex-smokers among 10,000 adult males in Israel. II. Physiological, biochemical and genetic characteristics. Am J Epidemiol 1997; 105: 75-86.

25. Wood PD, Stefanick MI, Dreon DM, Frey-Hewitt B, Garay SC, Williams $\mathrm{PT}$, et al. Changes in plasma lipids and lipoproteins in overweight men during weight loss through dieting as compared with exercise. N Engl J Med 1988; 319: 1173-9.

26. Rubins HB, Robins SJ, Iwane WK, Boden WE, Elam MB, Fye CL, et al. Rationale and design of the Department of Veterans Affairs HighDensity Lipoprotein Cholesterol Intervention Trial (HIT) for the secondary prevention of coronary artery disease in men with low highdensity lipoprotein cholesterol and desirable low-density lipoprotein cholesterol. Am J Cardiol 1993; 71: 45- 52. 